\title{
CARACTERISTICA AXIOLOGICĂ ȘI CEA CULTURALĂ A FAPTULUI ISTORIC ÎN CONCEPŢIA ISTORIOSOFULUI VASILE PÂRVAN
}

\author{
Petru DUNCA* \\ Claudiu HOLDIȘ ${ }^{* *}$ \\ Axiological and Cultural Characteristics of the \\ Historical Fact According to Historiosopher Vasile Pârvan
}

\begin{abstract}
Parvan brings the idea of the pluralism of history, which can manifest a real person in the essence of the evolution of society. The deeds of the spirit seek to dominate matter and to imprint nature's will with regard to the creation of new clear forms between plant and animal organisms, through persistent and systematic influence, to create face and create historical concerns exclusively. Becoming the anthropomorphic world and human life is the focus of the deep research and creation of the historian.
\end{abstract}

Keywords: philosophie, metaphisics, human being, pluralism of history, historical facts

Istoria este o scală a eternizării, a permanenței, aplicată coordonatei general-umane. Potrivit concepției rickertiene, unicul, particularul și individualul reprezintă conținutul istoriei. Acestea sunt faptele istorice, un corolar al întregii societăţi alcătuită din indivizii istorici rikertieni. Pe aceeași linie, Pârvan este convins că, o anumită „,pretenție de imortalizare nu poate avea decât un fenomen care din punctul de vedere al conţinutului lui spiritual corespunde unei valabilităţi cvasieterne”. Despre ,etern valabilul omenesc", Pârvan va afirma că, acesta ,în artă, credință, politică, filosofie, drept, etc. poate fi singurul obiect de preocupare al istoriei". Profesiunea de credință explicit expusă, nu poate să fie completă fără precizarea conform căreia, etern valabil „nu e decât ceea ce e supraaccidental, supracontemporan, supralocal; suflet omenesc în sine, în fața problemei vieții în sine. Iar legile după care ființa omenească evoluează în lume sunt legi cosmice". Stern va sublinia la rândul său specificitatea şi individualitatea faptelor istorice, dar şi caracteristica aceea conform căreia

\footnotetext{
* Prof. univ. dr., Universitatea Tehnică din Cluj-Napoca, Facultatea de Litere, str. Victoriei nr. 76, Baia Mare (duncapetru01@yahoo.com).

** Drd., Universitatea Tehnică din Cluj-Napoca, Facultatea de Litere, Baia Mare (holdisclaudiu@yahoo.com).
} 
ele au ceva în comun cu alte fapte de asemenea istorice ${ }^{1}$. Potivit aceluiaşi Stern, faptul istoric este purtătorul unei „valori specific”, caracteristică esenţială care lipsește ,faptelor natural ce se repetă" ${ }^{2}$. Cum am mai arătat și în alt capitol, faptele de cultură sunt esențiale pentru Pârvan în procesul dificil al reconstruirii trecutului istoric. În acest sens, istoricul român acordă o importanță extremă acestora. Aceste fapte de cultură, nu vor fi analizate sau evidențiate numai în contextul spiritual al epocii în care ele au avut loc. Nici pe departe. Pârvan le reconstruiește prin prisma „,eternului-uman”, fără de care nu ar putea exista o anumită continuitate a însăși procesului istoric, desfășurat în mod amplu între coordonatele și standardele sale ${ }^{3}$. Același Tănase va arăta că, Pârvan nu refuză caracteristica istoricităţii faptelor de cultură și nu poate fi vorba de căderea savantului român în linia prezenteismului. Pârvan aduce în prim plan o viziune de retrospectivă, detaşându-se într-un mod extrem de lucid. Prin această metodă el se va situa deasupra contemporanului însuși al respectivelor fapte aflate în analiza istoricului. Contemporanul faptelor respective, realizate în orice epocă istorică nu se poate confrunta cu obiectivitatea aferentă, atât de necesară unei analize pertinente. Mai mult, pentru cititorul avid de cunoaștere istorică, procedeul se impune printr-o anumită garanție a obiectivității ${ }^{4}$. Prin raportarea faptului istoric la ,eternul-uman”, rezultă că acesta se înscrie pe o scară a eternizării, a perenității efective ${ }^{5}$. Aceasta, deoarece eternul omenesc „,este identic cu cosmicul ${ }^{6}$. Istoricul este de fapt „,cosmicul din om”, astfel că „,istoria empirică, pe bază biologică, sociologică și individuală”, care „,socotește în evoluția omenirii ca întâmplare, soartă, intervenție divină ori pură absurditate logică", ${ }^{, 7}$ se înscrie pe un traseu deviant. O istorie a civilizației va fi concepută sau reconstruită cu ajutorul implicit al faptelor istorice dublate de o puternică și activă semnificație culturală. De aici și până a surprinde acțiunea lumii valorilor asupra lor, nu este decât un pas. Dacă anumite limite, sunt depășite din punctul de vedere al comprehensivității calitative de către faptele omenești, acestea nu mai intră în categoria faptelor istorice ${ }^{8}$. Caracterul istoric este conferit faptelor de „,semnificația lor culturală", 9 .

\footnotetext{
${ }^{1}$ Alfred Stern, La philosphie de l'histoire et le problème de valeurs, C.D.U., Paris, 1957, pp. 87-88.

${ }^{2}$ ibidem.

${ }^{3}$ Al. Tănase, Despre natura faptului istoric, în Filosofia istoriei. Studii (Al. Tănase, D. Hurezeanu coordonatori), București, Editura Politică, 1969, pp. 20-23.

${ }^{4}$ ibidem.

5 ibidem.

${ }^{6}$ Vasile Pârvan, Idei și forme istorice, București, Editura Cartea Românească, 2003, p. 76; ${ }^{7}$ ibidem pp. 76-77.

${ }^{8}$ Al. Tănase, Despre natura faptului istoric, în Filosofia istoriei. Studii (Al. Tănase, D. Hurezeanu coordonatori), București, Editura Politică, 1969, pp. 18-19.

${ }^{9}$ Ibidem.
} 
Avem o raportare acută la sistemul valorilor sau la valoare în general. Numai prin raportarea la valori putem distinge importanţa și esențialul faptului istoric. Este linia pe care va merge și Pârvan, întemeietorii acestei direcţii fiind Windelband și Rickert. Este coordonata neokantiană de partea căreia se situează și Pârvan, având accepțiunile sale proprii.

În ceea ce-1 privește pe Windelband, acesta are un original punct de vedere, potrivit căruia, istoria nu alege faptele care vor constitui obiectul ei de cercetare, aleator. Apoi, aceeași știință a istoriei, după alegerea faptelor, niciodată nu le va expune arbitrar, ea raportându-le permanent la un sistem de valori ${ }^{10}$. Astfel, orice fapt sau eveniment trecut, va fi evidențiat din totalitatea evenimentelor și faptelor trecute, grație raporturilor acestora cu o valoare sau sistem de valori. Fără permanenta raportare la valori, științele istorice nu ar fi cu putință. Nu numai științele istorice au această raportare la sisteme de valori. Potrivit aceluiași Windelband, povestirea sau crearea unor fabule implică o astfel de raportare tacită la valori, deoarece aici anumite fapte sunt reliefate, pentru că ele au o semnificație adâncă, au trezit interesul prin realitatea lor unică și ,l-a atras durabil asupra sa"11. În istorie, selecția și sinteza sunt determinate de valori universale, care au o valabilitate pentru toți indivizii. Doar că, descoperirea acestor valori, descrierea și determinarea lor cade în sarcina eticii, disciplină care are de îndeplinit un rol esențial în știința istoriei. În etică sălășluiesc, potrivit lui Windelband, ,principiile epistemologice ale științelor istorice" ${ }^{\prime 2}$. Etica trebuie să furnizeze filosofiei principiile respective. Prin raportarea la valori, istoricul dovedește legăturile pe care le au faptele trecute cu valorile recunoscute ca universal valabile. Istoria se ocupă cu faptele omului, descriindu-le și analizându-le, iar valorile la care sunt raportate aceste fapte trecute sunt valori umane. Sub același raport se înscriu și faptele sufletești, care vor prezenta de asemenea un interes aparte pentru istoric. Acestea nu vor fi expuse cu ajutorul metodelor psihologiei științifice, ci vor fi tratate ca fapte particulare ce-și păstrează semnificarea lor unică. Pârvan, subliniase la rândul său că ,fenomenele vieții omenești nu pot lua aspectul istoric, nu pot fi adică valori istorice, decât dacă viața lor intimă participă pasiv sau activ la o devenire superioară lor. În dualitatea natură, cultură, orice fenomen transformator al naturii, fie ea neînsuflețită, fie organică ori omenească, devine o valoare culturală: valorile culturale însă decurg din deveniri, sunt însemnate prin deveniri și se explică numai prin deveniri; ca fenomene izolate ele sunt ininteligibile și invalorabile" $" 13$.

\footnotetext{
${ }^{10}$ N. Bagdasar, Filosofia contemporană a istoriei, București,Tipografia Bucovina J.E. Torouțiu, 1930, p. 44.

${ }^{11}$ ibidem.

${ }^{12}$ ibidem.

${ }^{13}$ Vasile Pârvan, Idei și forme istorice, București, Editura Cartea Românească, 2003, p. 83.
} 
Pentru Rickert, așa cum am arătat mai sus, valorile sunt valabile și eterne. Actul de raportare a unui fapt trecut la o valoare istorică, nu cuprinde nimic din atitudinea personală a istoricului. El trebuie să-și țină în frâu idealurile, sentimentele și convingerile. Raportarea la valori este o caracteristică a logicii istorice, potrivit aceluiași Rickert. Nu voi stărui mai mult asupra reprezentanților școlii de la Baden. Am ținut să trasez aceste câteva caracteristici importante, pentru că ele au influențat gândirea lui Vasile Pârvan și nu numai a lui. Pârvan arată că istoria se scrie de pe alte poziții, ale universalității. Savantul român ,aderă la un criticism aprioric, logic și raționalist, conform căruia adevărata istorie se scrie numai de pe pozițiile universalității, mergându-se până la ignorarea valorilor fenomenelor istorice izolate în spațiu și timp" "14. Savantul român arată pe aceeași linie că, ,,în ritmica universală, orice explozie solitară a geniului individual nu poate cu nimic schimba vibrarea și ritmul devenirii eterne. Nu pentru că a existat Socrate, Alexandru, Isus ori Mahomed lumea noastră a devenit cum este, ci ea a devenit și devine cu toate că există și genii" ${ }^{15}$.

Potrivit lui Pârvan obiectul științei istoriei este unicul, faptele istorice neputându-se repeta în aceeași formă de două ori. Contemporanul lui Pârvan, Alfred Stern (1846 - 1936), arăta că în știința istoriei ,faptele ne interesează în primul rând pentru ce au ele specific, individual, iar în al doilea rând numai pentru ceea ce au ele în comun cu alte fapte" ${ }^{16}$. Și pentru Stern, „faptul istoric este purtătorul unor valori specifice”, acestea lipsind evident „faptelor naturale ce se repetă"17. Același Stern va evidenția aspectul unic și irepetabil al faptului istoric, prin exemplul fizicianului care consumă timp şi bani pentru a releva o anumită lege. Experimentul poate fi repetat în aceleași condiții, ba mai mult legea proaspăt decoperită, va putea fi înlocuită de o alta ca rezultat al unui experiment nou. În istorie lucrurile sunt total diferite ${ }^{18}$. Faptul istoric ,,are valoare datorită caracterului său unic", el neputând fi înlocuit cu alt fapt istoric ${ }^{19}$. Același lucru va fi susținut și de către Pârvan, care subliniază la rândul său unicitatea faptului istoric. Windelband va arăta că, istoria este disciplina unicului și individualului, având acea exactitate proprie, manifestată prin precizia criticii și siguranța stabilirii faptelor $^{20}$.

\footnotetext{
${ }^{14}$ Virgil Emilian Catargiu, Vasile Pârvan filosof al istoriei, Iași,Editura Junimea, 1982, p. 89.

${ }^{15}$ Vasile Pârvan, Idei și forme istorice, București, Editura Cartea Românească, 2003, p. 77

${ }^{16}$ Alfred Stern, La philosophie de l'histoire et le problème de valeurs, C. D. U., Paris, 1957 , pp. 81-82.

${ }^{17}$ Ibidem; vezi Mircea Florian, Fiinţă şi valoare în gândirea filosofică a lui Louis Lavelle, Bucureşti, Editura Academiei, 1979, pp. 78-130.

${ }^{18}$ ibidem pp. 92-93.

${ }^{19}$ ibidem.

${ }^{20}$ N. Bagdasar, Filosofia contemporană a istoriei, București,Tipografia Bucovina J.E. Torouțiu, 1930, pp. 43-44.
} 
Pârvan susține ca trăsătură esențială a istoriei, prezentarea faptului istoric unic, a irepetabilităţii acestuia, el petrecându-se o singură dată. Spre deosebire de alte științe, istoria susține acest lucru. Similaritatea opiniei lui Pârvan cu cea a lui Iorga reiese acum foarte clar. Iorga va începe oarecum într-o notă de amărăciune, arătând diferența dintre geograf și istoric: „,De mai mult timp geograful merge, și avem ca urmare altă geografie. Istoricul mărginit între anumite date şi anumite hotare va fi totdeauna mai slab înțelegător al esenței lucrurilor ce e menit să înfățișeze decât acela care îndrăznește a privi în jurul său. Faptele istorice nu se reproduc niciodată întocmai, ci au o noutate nesfârșită" ${ }^{21}$. Pârvan subliniase în repetate rânduri punctul său de vedere, conform căruia coordonata universalităţii trebuie aplicată istoriei, adevăratei istorii. Pentru aceasta se va impune chiar un anumit gen de trecere peste valorile fenomenelor istorice aflate într-o izolare, care sunt solitare în timp şi spaţiu. Astfel, în „dualitatea natură, cultură, orice fenomen transformator al naturii, fie ea neînsufleţită, fie organică ori omenească, devine o valoare culturală: valorile culturale însă decurg din deveniri şi se explică numai prin deveniri; ca fenomene izolate ele sunt ininteligibile şi invalorabile"22. Dar, subliniază mai departe gânditorul şi istoricul român, ,valorile culturale, adică spirituale, adică istorice, capătă adevărata lor proporţie în spaţiul evolutiv abia atunci când le aşezăm în mediul particular în care, energetic, îşi au valoarea lor maximă"23. Pârvan aduce interpretarea istoriei din perspectiva ,categoriilor supraistorice”, manifestându-şi ,predilecţia pentru filosofia istoriei, complementar istoriei propriu-zise"24. Aşa cum am mai subliniat şi în altă parte, istoria reconstituie evenimentele trecute, având parte de o anumită dificultate. Este destul de dificil a reconstitui realitatea obiectivă, chiar dacă filtrul critic al cognitivului subiectului cunoscător are parte de instrumentarul specific. Să nu uităm că istoria nu dispune de metode sau procedee de cercetare precum dispun alte ştiinţe, aici având în vedere experimentul, reacţiile chimice, etc. De aici decurge o anumită dificultate. Faptul istoric nu se poate repeta a doua oară în condiţii identice. În cazul în care lucrul acesta este posibil, dacă se repetă într-un alt timp dat, el va fi opera unui alt individ, subiect şi atunci repetitivitatea identică iese din discuţie. Individualul este caracteristica definitorie a faptului istoric. Aceeaşi concepţie o întâlnim la Iorga, exprimată în aceeaşi termeni. „Istoria este deci unul din modurile în care oamenii "repetă" apartenenţa lor la aceeaşi umanitate; ea este un sector al comunicării conştinţelor, un sector scindat de

\footnotetext{
${ }^{21}$ Nicolae Iorga, Generalități cu privire la studiile istorice, ediția a II-a, București, Casa Şcoalelor, 1933, p. 96.

${ }^{22}$ Vasile Pârvan, Idei și forme istorice, București,Editura Cartea Românească, 2003, p. 83.

${ }^{23}$ ibidem.

${ }^{24}$ Virgil Emilian Catargiu, Vasile Pârvan filosof al istoriei, Iași,Editura Junimea, 1982, p. 89.
} 
etapa metodologică a urmei lăsate şi a documentului, deci un sector distinct al dialogului, în care celălalt răspunde, dar nu un sector în întregime scindat al intersubiectivităţii totale care, ea, rămâne mereu deschisă şi în dezbatere" 25 . Este părerea unanimă influenţată de Marc Bloch a lui Ricoeur.

Faptul istoric este unic în natura lui, dar Pârvan arată că aici nu intră latura lor evenimențială. „Simpla descriere a faptului nu e decât o circumscriere formală, iar nu de conţinut, a fenomenului studiat" ${ }^{\text {"26. Faptul }}$ istoric are propria sa individualitate. Pe cale de consecinţă faptul istoric trebuie integrat într-un sistem, într-o structură, pentru a se transforma astfel în obiectul cunoaşterii istorice ${ }^{27}$. Mai mult, faptul istoric va reprezenta astfel o valoare sau va avea o anumită semnificaţie. Istoria reprezintă mulţimea fără sfârşit a faptelor care generează o anumită încărcătură plină de sens pentru om, putându-se raporta la lumea valorilor ${ }^{28}$. Dacă pentru artă sau ştiinţă, ,natura e obiectul şi ţinta supremă a prelucrării creatoare, pentru istorie, cultura e singurul obiect posibil”. Deoarece, ,numai unde începe cultura, adică manifestarea reformatoare umană în mediul natural cosmic, acolo începe istoria"29. Potrivit lui Rickert, discipolul de seamă al Şcolii de la Baden, valoarea face parte intrinsecă din ceea ce se numeşte obiect istoric. Aceasta, deoarece ,conceptul de valoare este acela care constituie principiul selectiv al istoricului'" 30 .

\footnotetext{
${ }^{25}$ Paul Ricoeur, Istorie şi adevăr, Bucureşti,Editura Anastasia, 1996, p. 40; Alfred Stern atrage atenţia asupra unei posibile obstaculări în ceea ce priveşte explicarea istoriei, dacă se foloseşte atât de des singularul ca şi sistem de referinţă; Stern arată că „metoda individualizantă” a istoriei sau „individualitatea” se face posibilă datorită existenţei concepţiei „evaluatoare a obiectelor”; mai mult „raportul cu o valoare se descoperă ca principiul constitutiv al obiectului istoric, care îl distinge de toate celelalte obiecte reale. Istoria - cunoaştere nuexistă deci decât pentru a fi evaluate".(Alfred Stern, La philosphie de l'histoire et le problème de valeurs, C.D.U., Paris, 1957, pp. 96-97)

${ }^{26}$ Vasile Pârvan, Idei și forme istorice, București,Editura Cartea Românească, 2003, p. 82;

${ }^{27}$ Potrivit lui Adam Schaff, ,(...) pot fi numite fapte istorice anumite manifestări ale vieţii indivizilor şi a societăţii, care sunt alese dintr-o mulţime de manifestări de acelaşi gen pe baza relaţiilor lor de cauză-efect şi a acţiunii lor în cadrul unei totalităţi mai ample. Criteriul alegerii îl constituie aici semnificaţia, importanţa evenimentului sau procesului dat sau a produselor acestuia. Se presupune, deci, un sistem de referinţă determinat, în cadrul căruia şi în funcţiune de care se operează valorizarea şi deci selectarea".(Adam Schaff, Istorie şi adevăr, București,Editura Politică, 1982, p. 244).

${ }^{28}$ Vasile Pârvan, Idei și forme istorice, București, Editura Cartea Românească, 2003, p. 90; ${ }^{29}$ ibidem p. 61.

${ }^{30}$ Alfred Stern, La philosphie de l'histoire et le problème de valeurs, C.D.U., Paris, 1957, pp. 96-97; Stern arată mai departe pe linia lui Rickert că, istoricul,,va alege ca esenţiale toate evenimentele din realităţile publice (res publica) care se raportează la valorile culturale - pentrucă ele contribuie la evoluţia acestor valori, la menţinerea lor, laamânarea sau retrogradarea lor. Contribuind din plin la retrogradareavalorilor culturale ale epocii noastre, Hitler este, aşadar, un fenomenesenţial al istoriei moderne şi constituie prin aceasta un obiect preţiospentru studiul istoric. Aceasta nu înseamnă însă că istoricul îl admirăsau îl iubeşte"(ibidem).
} 
Pentru Pârvan, „realitatea istorică în care oamenii îşi desfăşoară viaţa a devenit şi devine un produs al activităţii lor, un produs care reprezintă obiectivitatea forţelor omului şi care trebuie să fie în întregimea sa obiectul cercetării istorice" "31. Pârvan aduce asemeni lui Ricoeur ideea pluralismului istoriei, ca manifestare a faptelor oamenilor în esenţa evoluţiei societăţiii $^{32}$. Savantul român, vorbind despre obiectul cercetărilor istorice, subliniază că, faptele ,spiritului omenesc dominând materia şi imprimând naturii voinţa sa, până la crearea de noi forme chiar între organismele vegetale şi animale, prin influenţarea sa persistentă şi sistematică, aceste fapte şi creaţii alcătuiesc exclusiv domeniul preocupărilor istoricului" ${ }^{33}$. Astfel, devenirea „lumii şi a vieţii umane antropomorfe" este ,ţinta privirilor adânc cercetătoare şi creatoare ale istoricului" ${ }^{34}$.

La Pârvan vorbim de o anumită dualitate a conştiinţei istorice, pe palierul superior se află categoriile istorice, sinonime cu statul, dreptul, naţiunea, iar pe palierul inferior găsim accidentalul sau anecdoticul. Pentru ca faptele să devină istorie, trebuie ca sistemul să intervină cu toate mijloacele sale ${ }^{35}$. Faptul istoric se află în centrul disciplinei istoriei și relaţiile lui cu alte fapte istorice sunt esenţiale. Pentru a ne apropia de un eveniment și pentru a-1 studia, trebuie să cunoaștem ,tot complexul de urme pe care 1-a lăsat acel eveniment"36. Este părerea unanimă a marelui Iorga. Așadar faptele istorice reprezintă materialul cu care are a lucra istoricul. Necunoaşterea suficientă a acestora aduce cu sine lansarea unei lucrări neadecvate din punct de vedere științific. Faptele istorice sunt cele care ne dau informații despre ,evenimentele istorice sau despre caracteristicile vieții sociale și umane din trecut" ${ }^{\prime 37}$. Faptele istorice sunt elementele cu care istoricul recompune o imagine demult apusă, ele nefiind altceva decât informații despre anumite evenimente sau despre aspecte ale vieții sociale. Istoricul va lua anumite informații dintr-o vastă bibliografie istorică, care

\footnotetext{
${ }^{31}$ Virgil Emilian Catargiu, Vasile Pârvan filosof al istoriei, Iași,Editura Junimea, 1982, p. 90 .

${ }^{32}$ „Dacă spun "istorie" la singular, istoria este de asemeni istoria oamenilor, la plural, adică nu numai a indivizilor, dar şi a comunităţilor şi a civilizaţiilor.Un anumit pluralism este deci de asemeni înscris în pre-concepţia dramei istorice şi a muncii istorice. Nu numai că pun oamenii la plural, dar pun şi evenimentele la plural; dacă există un eveniment, există şi evenimente. Istoria este necesarmente o diversitate, o multiplicitate: este asta, apoi aceea. Aceşti "şi apoi", "şi după aceea", "şi pe urmă iar" fac să existe istorie. Dacă n-ar exista rupturi, înnoiri, n-ar mai fi deloc istorie". ( Paul Ricoeur, Istorie şi adevăr, Bucureşti,Editura Anastasia, 1996, p.88).

${ }^{33}$ Vasile Pârvan, Idei și forme istorice, București,Editura Cartea Românească, 2003, p. 61.

${ }^{34}$ ibidem.

${ }^{35}$ Nicolae Iorga, Generalități cu privire la studiile istorice, București,Casa Şcoalelor, 1933, p. 15.

${ }^{36}$ ibidem p. 52.

${ }^{37}$ Cătălin Zamfir, Filozofia istoriei, București,Editura Științifică și Enciclopedică, 1981, p. 39.
} 
are ca și țintă „să deie cercetătorilor într-o ordine metodică, înșirarea izvoarelor, a urmelor directe ale evenimentelor adecă, precum și a cărților scrise pe baza acestor izvoare și a lucrărilor care tratează despre monumentele nescrise, pe care le studiază științe auxiliare ale istoriei”,38. Faptele sunt culese și analizate de istoric vor purta amprenta acestuia. În momentul în care subiectul recunoaște un fapt istoric, el va încerca să adune toate componentele respectivului fapt și să determine absolut toate relațiile(dacă lucrul este cu putință) cu alte fapte istorice, împreună cu limitele sale temporale, respectiv spațiale. După această etapă, faptul istoric proaspăt reconstituit va fi integrat într-un ansamblu mai mare. Aici intervine experiența și inteligența subiectului cunoscător. Potrivit lui Iorga, unele izvoare sunt incomplete, cu cât înaintăm mai înapoi în istorie și atunci istoricul va face apel la critică și la fantezie pentru a umple anumite goluri. Odată ce dimensiunea critică este realizată, istoricul își formează propria convingere asupra faptului istoric, drept pentru care „rămâne să o spuie”. Și începând de acum ,începe opera de artă și talent. Muncă, inteligență și talent: toate trei trebuie să le aibă adevăratul istoric.

O primă interpretare ar fi cea ontologică, aceasta prezentând faptul istoric exact ca și ,un obiect al cercetării istorice”, acesta existând independent de obiectul cunoscător. Istoricul, ia act de obiectul cunoașterii istorice, în speță evenimentul, care este constituit dintr-o serie de fapte determinate. Același istoric, va reconstitui sau reconstrui respectivul eveniment prin „reflectarea” acestor fapte în conștiința sa. O altă interpretare va intra pe tărâm epistemologic și metodologic, în sensul în care se referă efectiv la procesul de reconstituire a faptului istoric. Această reconstituire este denumită generic drept fapt istoriografic. În privința raporturilor dintre cele două interpretări, faptul istoric este interpretat atât din punct de vedere ontologic, cât și din punct de vedere gnoseologic. Se mai întâlnește și modalitatea de a trata faptul istoric într-o manieră pur științifică, adică istoriografică, fără a mai căuta corespondența în realitatea istorică. Prima modalitate aparține pozitivismului, a doua fiind specifică structuralismului, aici ,subiectul are un rol activ în crearea realității examinate" 39 . Interpretarea pozitivistă este cea preferată de majoritatea istoricilor, pentru că ,realitatea se compune dintr-un anumit număr de fapte cheie, pe care istoricul pur și simplu le reconstruiește. Această reconstruire trebuie să fie în concordanță cu faptele, iar, la rândul ei, această concordanță constituie un criteriu al veridicității" ${ }^{40}$. Pe de altă parte, tabăra care vede în faptul istoric doar „,o construcție științifică este adesea criticată” aceasta

\footnotetext{
${ }^{38}$ Nicolae Iorga, Generalități cu privire la studiile istorice, București, 1933, pp.52-53.

${ }^{39}$ Jerzy Topolski, Metodologia istoriei, București,Editura Științifică și Enciclopedică, 1987, p. 154.

${ }^{40}$ ibidem.
} 
fiind „o manifestare a așa - numitului subiectivism, respectiv a tendinţei istoricului de a crea o realitate istorică proprie". Această linie critică se impune doar în cazul în care „,o astfel de concepție este corelată cu negarea unei realități obiective, independentă de subiectul care ia cunoștință de ea, pentru că în acest caz avem de-a face realmente cu o construcție subiectivă a realității istorice din partea cercetătorului" "41. O a treia interpretare „,recunoaște existența unei realităţi obiective, independente de subiectul care ia cunoștință de ea” și consideră că ,această realitate nu este deloc o mulțime de fapte date, care trebuie numai să fie reflectate în conștiință și reconstruite". Este vorba de o recunoaștere concomitentă a existenței „realităţii istorice obiective ca obiect al cercetării și rolul cognitiv creator al gândirii istoricului". Această interpretare se numește dialectică ${ }^{42}$. Ea avansează ideea potrivit căreia ,realitatea istorică este complexă, bogată și cu nenumărate legături interne, că reconstituirea faptelor este o formă indispensabilă a cunoașterii ei simplificate, respectiv apropierea de adevărul absolut prin intermediul adevărului aproximativ"43. Părerile aparțin unui reputat profesor și cercetător, Jerzy Topolski (1928-1998), a cărui lucrare „Metodologia istoriei”, a fost publicată în 1968. Sinteza pe care o face curentelor de interpretare a faptului istoric în epoca în care Pârvan a trăit sunt de o mare profunzime și simț analitic. Lucrarea apare mult după ce Pârvan se stinge prematur din viață, dar sinteza făcută de profesorul polonez descrie o epocă de mari controverse, benefice pentru știinţa istoriei. Lucrurile nu au fost cristalizate foarte limpede la începutulsecolului XX, drept pentru care istoricii aflaţi la început de drum, dădeau crezare pozitivismului, care de altfel a introdus în metodologie conceptul de fapt istoric. Interpretările acestuia diferă de la caz la caz.

Onciul, Bogdan sau Iorga, simt aceste noi linii de cercetare şi putem observa cum aceștia devin tributari unor astfel de concepții. Este ,școala critică" românească ai căror reprezentanți pun un accent deosebit pe critica izvoarelor istorice și pe reconstrucția faptului sau evenimentului istoric. $\mathrm{Pe}$ aceeaşi coordonată se va înscrie şi Pârvan, gânditorul şi istoricul român creator unei noi şcoli de cercetare.

În concluzie putem afirma că istoricii spaţiului românesc nu sunt străini, ba chiar sunt implicaţi în găsirea noilor modele de cercetare aplicată în domeniul istoriei. Faptul istoric se află în centrul disciplinei istoriei. Este un inel fie din ceea ce se numeşte res gestaesauhistoriaererumgestarum. Istoricii români erau familiari cu liniile cercetării schiţate de Charles Victor Langlois, Charles Seignobos, Carl L. Becker, Dilthey, Windelband sau Rickert. Creatorii noii şcoli româneşti critice, un Bogdan sau un Onciul, se

\footnotetext{
${ }^{41}$ ibidem.

${ }^{42}$ ibidem.

${ }^{43}$ ibidem.
} 
vor centra pe faptul că omul se află în centrul istoriei, iar faptele sale au o importanţă deosebită pentru comunitatea socială, dar şi pentru dezvoltarea omenirii. Individul şi faptele sale dobândesc valoare socială. Încununarea respectivei concepţii, dublată de linia metafizică este realizată de Pârvan în spaţiul românesc.

\section{Bibliografie}

Bagdasar, N. Filosofia contemporană a istoriei, București,Tipografia Bucovina J.E. Torouțiu, 1930.

Catargiu, Virgil Emilian. Vasile Pârvan filosof al istoriei, Iași,Editura Junimea, 1982.

Florian, Mircea. Fiinţă şi valoare în gândirea filosofică a lui Louis Lavelle, Bucureşti, Editura Academiei, 1979.

Iorga, Nicolae. Generalități cu privire la studiile istorice, ediția a II-a, București, Casa Şcoalelor, 1933.

Pârvan, Vasile. Idei și forme istorice, București,Editura Cartea Românească, 2003.

Ricoeur, Paul. Istorie şi adevăr, Bucureşti,Editura Anastasia, 1996.

Schaff, Adam. Istorie şi adevăr, Bucureşti,Editura Politică, 1982.

Stern, Alfred. La philosphie de l'histoire et le problème de valeurs, C.D.U., Paris, 1957.

Tănase, Al. Despre natura faptului istoric, în Filosofia istoriei. Studii (Al. Tănase, D. Hurezeanu coordonatori), București, Editura Politică, 1969.

Topolski, Jerzy. Metodologia istoriei, București,Editura Științifică și Enciclopedică, 1987.

Zamfir, Cătălin. Filozofia istoriei, București,Editura Științifică și Enciclopedică, 1981. 